\title{
Bark beetles of the genus Dryocoetes (Coleoptera: Scolytidae) in North America
}

Donald Edward Bright Jr.

Brigham Young University - Provo

Follow this and additional works at: https://scholarsarchive.byu.edu/etd

Part of the Life Sciences Commons

\section{BYU ScholarsArchive Citation}

Bright, Donald Edward Jr., "Bark beetles of the genus Dryocoetes (Coleoptera: Scolytidae) in North America" (1961). Theses and Dissertations. 7635.

https://scholarsarchive.byu.edu/etd/7635

This Thesis is brought to you for free and open access by BYU ScholarsArchive. It has been accepted for inclusion in Theses and Dissertations by an authorized administrator of BYU ScholarsArchive. For more information, please contact ellen_amatangelo@byu.edu. 
BARK BEETLES OF THE GENUS DRYOCOETES

(COLEOPTERA: SCOLYTIDAE) IN NORTH ANERICA

\author{
A THESIS \\ SUBMITTED TO \\ THE DEPARTMENT OF ZOOLOGY AND ENTOMOLOGY \\ BRIGHAM YOUNG UNIVERSITI
}

IN PARTIAL FULFILCMENT OF THE REQUIREMENTS FOR

THE DEGREE OP

MASTER OF SCIENCE

BY

DONALD EDWARD BRIGHT, JR.

JUNE, 1961 
This Thesis by Donald Edward Bright, Jr. is accepted in its present form by the Department of Zoology and Fintomology of Brigham Young University as satisfying the Thesis requirement for the degree of Master of Science.

June, 1961 


\section{ACKNOWLEDGEMENTS}

Many individuals contributed to this study. Sincere appreclation 1s expressed here to Dr. S. L. Wood, Brlgham Young University, who ruggested it, furnished much information about this genus and its relatives, allowed the author free access to his collection, read and edited the manuscript of this paper and also offered encouragenent and help in every way. Thanks are also offered to Dr. E. M. Christensen, Brigham Young University, who also read the manuscript and offered helpful suggestions.

To the following individuals and institutions sincere appreoiation is given for the loan of specinens: U. S. National kuseum for the loan of their specimens; Dr. W. H. Anderson and Dr. D. M. Anderson, Insect Identification and Parasite Introduction Research Branch, U. S. Department of Agriculture for arranging the loan of the National Museum specimens; Mr. W. J. Brown, Entomological Research Institute, Research Branch, Canada Department of Agriculture, Ottawa; and Mr. H. B. Leech, California Acadamy of Solence.

To the staff and students of the Zoology and Entomology Department of the Brigham Young University, gratitude is expressed for their interest and suggestions.

Special thanks are given to my wife, Merlene, for her help and encouragement during the course of this study. 
TABLE OF CONTENTS

Page

ACKNOWLEDGEMENTS, ...................... 111

LIST OF CHARTS .......................... v v

LIST OF ILLUSTRATIONS ...................... v vi

INTRODUCTION ......................... 1

HISTORY .............................. 3

METHODS ............................ 5

INTRASPECIFIC VARIATION .................. 7

Sexual Variation ..................... 7

Individual Varlation. ................... 7

Geographical Variation. ................. 8

DISCUSSION OF CHARACTERS. .................. 11

PHYLOGENY ......................... 15

SYSTEMATIC SECTION, ........................ 17

Genus Dryocoetes..................... 17

Key to the species of the genus Dryocoetes. . . . . . . . 20

Dryocoetes autographus (Ratzeburg). ............. 23

Dryocoetes betulae Hopklns. . . . . . . . . ...... 28

Dryocoetes confusus swaine. ................. 31

Dryocoetes granicolizis (Leconte)............ 34

Dryocoetes affaber (Mannerheim) ............ 37

Dryocoetes sechelt1 swaine. . . . ........... 41

Dryocoetes caryl Hopkins. . . . . . . . . . . . . . 43

LITERATURE CITED. ...................... 45

ABSTRACT. .......................... 48 


\section{LIST OF CHARTS}

Chart $\quad$ Page

1. Variations in size of Dryocoetes affaber. . . . . . . . 9

2. Variations in size of Dryocoetes autographus. ........ 9 


\section{IIST OF ILLUSTRATIONS}

IIlustrations

Page

Fig. 1. Dorsal aspect of pronotum of Dryocoetes granicollis, , 47

Fig. 2, Dorsal aspect of pronotum of Dryocoetes affaber. ... 47

Fig. 3. Dorsal aspect of pronotum of Dryocoetes autographus. * 47

Fig. 4. Antenna of Dryocoetes affaber. . . . . . . . . 47

Fig. 5. Male genitalla of Dryocoetes caryi ......... 47

Fig. 6. Male genitalia of Dryocoetes sechelti. . . . . . 47

Fig. 7. Male genitalla of Dryocoetes granicollis . . . . 47

Fig. 8. Male genitalia of Drrocoetes affaber . . . . . 4 47

Fig. 9. Male genitalia of Dryocoetes betulae . . . . . 47

Fig. 10. Malo genitalla of Dryocoetes confusus. . . . . . . 47

Fig. 11. Male genitalla of Dryocoetes autographus . . . . 47 


\section{INTRODUCTION}

The genus Dryocoetes is widely distributed in Europe, Asia, North merica and Central America. It consists of about sixty species, seven if which occur in North America.

All seven species in North America bore in the bark of the host ree whore they feed and reproduce in the phloem layer. Usually they are 'ound in the larger part of the bole or near the ground line feeding in 'oots. The species generally are host specific, limiting their attacks - two or three genera of trees. Only one North American species, etulae, attacks brosdleaf trees; the remainder feed in coniferous rees, usually Picea or Abies. Since these insects feed for the most rart in dying or injured trees and windfalls, direct economic loss is enerally nil. However, confusus may attack and kill apparently healthy rees.

As far as known all species in the genus are polygamous, ordinarily ith about three or four females sssociated with one male. Apparently, he male begins the entrance tunnel and hollows out the nuptial chamber here he waits for the females. In the cambial layer, each female onstructs an egg gallery that radiates from the nuptial chamber. Eggs re laid along the gallery in niches and then covered with frass. The 'emale pushes her excess boring dust toward the entrance where it is xpelled by the male.

Mathers (1931) states, in the case of confusus, that the adults 
emerge from hibernation in the latter part of June and fly until late July. Soon after emerglng, they attack new trees where they excavate the first brood tunnels. Eggs are laid in these tunnels until late August, the beginning of cold weather, when the adults excavate feeding and hibernating tunnels. The male gallery extends from the nuptial chamber and the female continues the egg tunnel, these portions being recognized by the absence of egg niches. The parent adults psss the winter in these galleries. At the beginning of warm weather in the spring, the female beetles continue their galleries, laying eggs in the freshly cut portions. Egg laying continues unt1l late June or early July, after which the parent adults may emerge and attack a new tree or they may die in the galleries. The first brood of eggs hatch by late August and pass the winter as young larvae. Pupa of this brood are present in late July or early August of the following year and transform to adults in late August. These young adults remain in the trees until spring, thus giving a life cycle of two jears.

The two year life cycle described above is probably true only in the northern portion of the range of confusus. In the western and southwestern United States, the life cycle evidently may be completed in one year or less.

The tribe Dryocoetini is large and complex. Its systematics cannot be adequately understood until all included genera are redefined and revised. The present study, although limited to North America, is a contribution to our knowledge of Dryocoetes Eichhof, the largest genus in this group. It was undertaken because no revisional study is available to assist in the identification of North American species. 
HISTORY

The genus Dryocoetes was described by Elchhoff (1864, p. 38) to Include four European species: Bostrichus autographus Ratzeburg, B. cryptographus Ratzeburg, B. dactyliperda Fabriclus, and B. V1110sus Pabricius. Of these, Be cryptographus was transferred to Xyleborus by Eichhoff (1881, p. 276), and $\underline{B}_{2}$ datyliperda was made the type of Coccotrypes also by Eichhoff (1879, p. 309). Eichhoff (1864, p. 38) further stated that probably $\underline{B}_{e}$ alni George. and apparently B $_{\text {f bicolor }}$ Herbet (transferred to Taphrorychus, Eichhoff (1879, p. 205)) should be included in Dryocoetes. Since then, numerous species from North America, Central America and Eurasia have been described.

In the only other division of the genus, Balachowsky (1949, p. 178) erected the genus Dryocoetinus for alni and villogus, based on the almost totally granulate pronotum, with punctures on the anterior portion of the disk, and the deeply impressed sutural interspace at the apical portion of the declivity of these species. This new division has not been accepted by later workers, and Schedl (date unavailable)placed this genus in synonomy.

The first North American species of Dryocoetes was described as " Bostrichus septentrionis by Mannerheim (1843, p. 298). In 1852, Mannerheim described a second species, affaber (p. 359), also in the genus Bostrichus, and Leconte (1868, p. 162) a third, granicollis as a Xyleborus. The remaining North American species were described as 
Dryocoetes by Hopkins and Swaine. In 1912, Swaine described pubescens

(p. 350) and confusus (p. 351); in 1915, seche1ti (p. 350) and pseudotsugae (p. 360) were described. Mopkins, in 1915a, described betulae (p. 50), caryi (p. 50), americanus (p. 51), liquidambaris (p. 51) and picese (p. 51). 
METHODS

Approximately four thousand specimens of Dryocoetes were examined during this study, including the allotype of caryi and one broken paratype of sechelti. Of the remaining species, specimens of betulae, piceae, and confusus which bore the same data as the type, but not designated as paratypes, were seen. Specimens of americanus determined by Hopkins and gpecimens of affaber, granicollis and pubescens determined by Blackman were examined. The 1dentification of septentrionis is based on a specimen in the collection of $\mathrm{S}$. L. Wood which had been compared by him to the Mannerhelm specimen in the Canadian National Collection.

After dissecting the male genitalic capsule from a specimen, the capsule was placed in a cold five per cent potassium hydroxide solution until the muscle fiber had dissolved away. The capsule was then washed in water several times, and transferred to microvials containing glycerine. The dissected specimen was remounted and the vial containing its genitalia was placed on the pin for future reference. A minimum of two to four specimens per species were used for each of the above dissections.

Illustrations were prepared with the aid of an ocular grid. The antennal drawing was made from a Canada balsam slide preparation; those of the male genitalia were made while the genital capsule was immersed in glycerine; and pinned specimens were used for drawings of the pronotums. Measurements were made by using a callbrated ocular grid. These 
easurements represent the averages of many measurements and should be sed with caution since some specimena may not fall in the size range hat is stated. 


\section{INTRASPECIFIC VARIATION}

\section{Sexual Variation}

Sexual variation was observed in all species of North American Dryocoetes. In the small species, sechelti, caryi and granicoliis, the differences are slight and very difficult to detect. Generally, the female has more hair-like pubescence on the frons and somewhat larger granules on the elytral declivity.

The most striking sexual variation in this genus occurs in confusus, where the female frons is very densely, closely halry with the short seta longer at the periphery. The male frons is convex, granulatepunctate and only sparsely halry. The sutural interspace of the elytral declivity is more strongly elevated and more coarsely granulate in the female.

In the other large species, the frons of the female is flattened or slightly concave and usually more or less densely clothed with hairs, whereas that of the male is convex or smooth and punctured and only sparsely hairy.

\section{Individual Variation}

Variation in body length was noted in all species, but is prominent only in two. The difference in length between the largest and anallest specimens equalled about thirty percent of the smallest. Environmental factors evidently influence the size of the individuals, since host conditions, such as molsture content and temperature are important agents. 
Body color generally is conststent throughout the genus, varying from reddish-brown to almost black. The imature specimens are Hghter In color, and gradusily acquire the mature, darker color.

The ourface of the pronotum often exhibite differences between Individuals of the same series. Certain specimene of autographue have the anooth wedian line obscured by punctures and esperit1es. Other spectene may show alfference in the size and abundance of punctures. The pronotal shape may also show alight variation. For example, in most specinen of affaber the pronotum is triangular $\left(F I_{g}, 2\right)$, but occesionaliy it way be more rounded, with the widest part more toward the midle. In 1ndividusis of all species, variations in placenent and depth of punctures, and in size and surface sculpture of asperities may be found.

The elytral disk and decllvity also show slight variation within a series. No one epectes can be eingled out for discussion, since the varlations are observed in all species. The most prominent individual difference occurs in the size, depth and distribution of the punctures on the elytral djek and in the degree of elevation of the sutural striae on the deculvity. Other characters that may vary are the amount and length of pubescence, the abundance of interatrial punctures and the size of the granules of the declivity.

\section{Ceographical Varlation}

Geographical variation was noted especially in the late of specimens of affaber and autographue from different areas of their ranges (Charts 1 and 2). These species exhibited a gradusl incresse in alse from the eatem and southeastern portion of their ranges to the north- 
westem and northern parts. The largest average size of both opecies io reached between Orogon and Alaska.

\begin{tabular}{|c|c|c|c|c|}
\hline \multirow[b]{2}{*}{ Looflity } & \multirow[b]{2}{*}{$\begin{array}{l}\text { Number of } \\
\text { Specimene }\end{array}$} & \multicolumn{2}{|c|}{ Siso in $=$} & \multirow{2}{*}{$\frac{\cdot}{\text { Averago }}$} \\
\hline & & Kaxdraum & Minimum & \\
\hline Malne & 10 & 2.60 & 2.30 & 2.45 \\
\hline $\begin{array}{l}\text { Miohlgan and } \\
\text { Minnesota }\end{array}$ & 10 & 2.75 & 2.35 & 2.58 \\
\hline Colorado & 10 & 2.80 & 2.40 & 2.50 \\
\hline Utah & 10 & 2.85 & 2.50 & 2.74 \\
\hline Oregon & 20 & 3.00 & 2.25 & 2.70 \\
\hline British Columbia & 10 & 3.50 & 2.50 & 2.88 \\
\hline $\begin{array}{l}\text { Juneau, Alaska } \\
\text { (near type logality) }\end{array}$ & 10 & 3.25 & 2.70 & 3.10 \\
\hline
\end{tabular}

Chsrt 1. Variations in sise of Dryocoetes affaber.

\begin{tabular}{|c|c|c|c|c|}
\hline \multirow[b]{2}{*}{ Loeal1ty } & \multirow[b]{2}{*}{$\begin{array}{l}\text { Numbor of } \\
\text { Spectimens }\end{array}$} & \multicolumn{3}{|c|}{ Size in m. } \\
\hline & & Maxdoum & Yinimim & Average \\
\hline Malne & 10 & 3.80 & 3.10 & 3.40 \\
\hline Quebec & 10 & 4.00 & 3.10 & 3.53 \\
\hline $\begin{array}{l}\text { Michlgan and } \\
\text { Minnesota }\end{array}$ & 10 & 4.20 & 3.25 & 3.70 \\
\hline Northwest Territory & 20 & 4.15 & 3.50 & 3.81 \\
\hline Alberta & 10 & 4.25 & 3.50 & 3.85 \\
\hline $\begin{array}{l}\text { Junoau, Aladka } \\
\text { (nosar type lockllty) }\end{array}$ & 10 & 4.75 & 3.75 & 4.25 \\
\hline England & 10 & 4.00 & 3.25 & 3.65 \\
\hline
\end{tabular}

Chart 2. Variation in sise of Dryocoetes autographus. 
The charts on the preceding page shov the rang in 1 ize of series from verlous localities and 11luatrates the gradual increase in aise from southeestern to northwestern areas. A veries of autographus from Europo 1. Included in Chart 2 to show the size of specimens from that area.

In the eastern part of 1ts range, the declivital punctures of affaber are scusewat angller than those from the west. On some Individuals of this species from colorado and Utah, the declivital punetures are larger and more coarse; this can also be seen on specimens from all parts of its range. This variation evidentls is somewhat comon In the intermountain roglon, wore than in other areas. The size of the declivital granules also varies from eas to wast; those whth aller granules being more comon in the eat. Speciment of autographus from the eatern portion of its range aloo have smaller declivital granules, and somewhat smaller elytral punctures. In specimens of confusus frosn Arizona, the sutural strine are comparatively more atrongly elevated than in specimens from farther north. 


\section{DISCUSSION OF CHAFACTERS}

The classification of the genus Dryocoetes in North America was formerly based by Swaine (1918) on size, localtty and host; morphology boing used to indicate species groups. A thorough analysis of all the characters useful in the classification of the family scolytidae is not arailable nor have all the possible characters been investigated. The most useful characters used in this study are briefly discussed.

The genus Dryocoetes belongs in the tribe Dryocoetini in the subPamily Ipinae, Other related genera in this tribe include Taphrorychus Eichhoff (Europe), Grytogenius Strohmeyer (Africa), Ozopemon Hagedorn (southeast ABis), and Carposinug Hopkins (southeast Asia). These genera are distinguished from all other scolytid genera by the evenly convex pronotum; by the obliquely truncate antennal club (or possessing a club derived from that type); by the flattened, spinose distal portion of the tibige and by the convex or flattened, unarmed, granulate declivity.

These genera may be distinguished from one another by several characters, the most important of which are the characters of the antennal club. In Taphrorychus, the antennal club is clrcular, with the thickened basal area occupying less than one-fourth the total length and margined distally by a recurved line, the female frons is concave with a dense pile of short halrs and the declivity is convex with the sutural striae more strongly convex. Crytogenius may be distinguished by the clrcular club, as in Taphrorychus, but the club has no basal corneous 
area. It may also be distinguished by the four-segmented antennal funicle, by the impressed elytral striae and by the scutellum being wider than 1ong. In Ozopemon, the club is more pointed at the distal end, the corneous basal portion occupying less than half the total length, with the first suture Indicated by a scleritized procurved line; the pronotum is much wider than long, with a diatinct summit and acute asperities; the scutellum is V-sheped. Carposinus is distinguished by the sub-truncate, circular antennal club; by the impressed elytral striae; by the indefinite pronotal sumit and by the V-shaped scutellum.

Prons

The pubescence of the frons of the female is extremely valuable in the classification of the genus. It varies from densely clothed, completely hiding the surface of the frons in confusug, to only eparsely clothed in autographus. The surface may be smooth and minutely granulate, as in granicollis, to moderately roughened, as in autographus.

In the male, frontal variations are less obvious, but nevertheles 6 are present. For example, the frons is distinctiy punctured and smooth In sechelti but roughly granulate-punctate in confusus and, to a lesser extent, in affaber. Pubescence of the male frons varies but little.

\section{Antenna}

(Fig. 4)

The antennal scape is slightly longer than the funlele, slender, and widened at the distal end. The funicle is five-segmented, longer than the club, with the pedicle enlarged and cup-shaped, with segments two to five smaller and gradually increasing in size distally. The club 
is obliquely truncate with the truncate portion occupying less than half the club in all spectes. The shape varies from sub-oval, approxdmately 1.4 times wider than long in autographus, to slightly longer than wide in affaber. The distal pubescent portion of the club projects beyond the corneous apex on the posterior face in autographus, betulae and granicollis. In the other speciss, no pubescence can be seen projecting beyond the apex. This cheracter was not included in the key, since many specimens have the antennae lying close to the body, making observation of this character impossible.

\section{Prorotum}

The shape of the pronotum varies from somewhat triangular in caryl, sechelti and affaber (Fig. 2), to more nearly clreular in betulae, confusus and autographus (F1g. 3), and elongate with parallel sides in granicollis (Fig.1). In autographus, the surface of the pronotum is closely, densely punctured over the posterior two-thirds, the punctures being obscured, but still visible, by small asperities on the anterior portion. The surface of the pronotum in affaber is asperate over the entire surface tending to become granulate on the posterior one-fourth. In some specimens of affaber, a few small obscure punctures may be seen. The pronotal surface of granicollis is also asperate with a few shallow punctures.

\section{Elytra}

The sutural striae on the elytral disk may be impressed as in granicollis, or unimpressed as in affaber. The striae are regularly punctured in rows, varying greatly in depth and size between individuals. 
The interspaces are smooth and minutely punctured in all species, except granleollis where they are roughened by the large, impressed atrial punctures.

As in many scolytids, the declivity offers excellent characters. In granicollis, the autural striae are deeply impressed making the suture atrongly and prominently elevated, and the striae are deeply punctured. In confusus and betulae, the sutural striae are much less impressed and the suture is only moderately levated. The renaining specles have the sutural striae very slightly impressed, if at all and a feebly elevated suture.

T1bias

The tibiae are slightly curved, widened at the distal ond, abruptly truncate, and margined by from five to seven teeth. The number of teeth varies between individuals and even may vary in the same apecimen. For this reason, the tibiae were of no value in the classification of the genus.

\section{Male Coaltalis}

Freellent charectare ware found on the endophallite portion of the

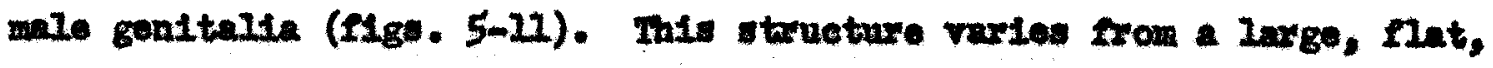
sac-11ke form, as in autogetaphns, contuaus, betaine and aftabes, to moderately lobed in eary and ceobelts and deeply lobed in granteolity.

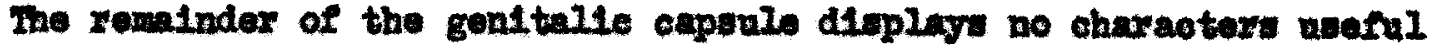
In the deternination of ppoles. For this reason, the raxlous atructurea are not numed and no attempt is made in this aty to homologise the structures with those of other mperiem. 


\section{PHYLOGENY}

Since the present study only includes a small fraction of the species of the genus Dryocoetes, a thorough discussion of the phylogeny of the group is not possible. A fow general statements can be made, however.

Sexual dimorphism of the same general type is present to varying degrees in all the genera related to Dryocoetes. Any extreme development of these characters may be considered a specialization since they do not occur generally in other scolytids. The larviform male of ozopemon brownei, (Browne, 1957), is certainly a specialization." The reduction in number and size of strial and interstrial punctures and the reduction in number of pronotal asperities in Ozopemon are other specialized characters. Since reduction in number or size of parts is indicative of specialization, the four-segmented antennal funicle of Crytogentus may be considered specialized. The antennal club of related genera is obliquely truncate, except in Crytogenius, where the club has no basal corneous portion and is not obliquely truncate.

From the above line of reasoning, it is thought that ozopemon . and Crytogenius represent the more specialized genera in this discussion. Dryocoetes, because of the low degree of sexual dimorphism (except in three species), its obliquely truncate antennal club, moderate to large strial punctures and only a slight reduction in number of tibial spines, is considered to be a comparatively unopecialized genus.

These genera appear to have evolved from a common ancestral stock. 
which probably had its center of distribution in Eurasia. In order to determine this hypothetical parent, approximately fifteen species in the five genera mentioned above were studied and analyzed. The author's concept of the hypothetical ancestor is most nearly fulfilled in the genus Dolurgus, which some authors place in the Dryocoetini. Dolurgus superficially resembles Dryocoetes and shows many of the same characters in a more primitive form. Sexual dimorphism is not evident, the antennal club shows a primitive obliquely truncate form, pronotal asperities are not developed and the anterior tibiae have six or more spines. Among North American Dryocoetes, two lines of specialization are apparent. Along one line, the extreme advanced characters are the deeply impressed sutural striae of the declivity, the enlarged pronotum with parallel sides and the peculiar male genitalia shown by granicollis. Alorg the same line but less specialized are caryi and sechelti. The eecond line of specialization is illustrated by the sexual dimorphism, the reduced elytral punctures and the host specifieity of betulae and confusus. The least specialized characters such as a convex, not impressed declivity, low degree of sexual dimorphism and unspecialized male genitalia are found in autographus. The position of affaber is uncertain, but it appears to be intermediate between the betulae-confusus group and autographus.

The above discussion, unfortunately, must be largely speculation, Since the tribe Dryocoetini is very large and occurs throughout the world, a thorough consideration of phylogeny is impossible at this time. 


\section{SYSTEMATIC SECTION}

Genus Dryocoetes Ef chhoff

rocoetes Bichhoff, 1864, Berliner Ent. Zeitschr., 8: 38; 1879,

Roy. soc. sei. Liége, Mem., Série 2, 8: 283; __, 1881, Die europäischen Borkenkäfer, p. 261; Leconte, 1876, Amer. Philos. Soc., Froc. 15: 358; Provancher, 1877, Petite Faune Entomologique du Canada, 1: 568; Bedel, 1888, Annales de 1a Soclete Entomologique de France, 6: 396, 400; Judeich and Nitsche, 1895, Lehrbuch der mitteleuropäischen Forstinsektenkunde 1: 449; Blandford, 1898, Bio1. Centrali-Americana, Coleoptera 4(6): 186, 189; Barbey, 1901, Les Scolytides de 1'Europe centrale, p. 100; Felt, 1906, New York St. Mus. Mam. 8(2): 337; Tredl, 1907, Entomologische Blätter, 3: 17; Swaine, 1909, New York St. Mus., Bull. 134, In Rept. of St. Ent. for 1908, Appendix B, p. 101; Hagedorn, 1910, Coleopterorum Catalogus, 4: 65; Reitter, 1913, Wiener Ent. Zeitschr. 32, 75; Hopkins, 1914, U. S. Nat. Mus., Proc. 48: 121; Blatchley and Leng, 1916, Rhynchopora of North Eastern America, p. 610, Swaine, 1918, Dom. Canada Dept. Agric. Ent. Branch, Tech. Bull. 14(2): 128; Blackman, 1922, Miss1ssippl Agric. Expt. Sta., Tech. Bull. 11: 120; Dodge, 1938, Univ. Minnesota Agric. Expt. Sta., Tech. Bull. 132: 54; Chamberlin, 1939, The Bark and Timber Beetles of North America, p. 462; Beal and Massey, 1945, Duke Univ. School of Forest., Bull. 10: 159; Balachowsky, 1949, Fauna de France 50: 177; Stark, 1952, 
Fauna U. S. S. R. 31: 323; Chamberlin, 1958, Scolytidae of the Northwest, p. 188.

Dryocoetinus Balachowsky, 1949, Fauna de France 50: 188.

This genus is distinguished from related genera by the granulate to punctate, evenly convex pronotum, with low, indistinct asperities; by the obliquely truncate antennal club with the basal portion reaching beyond the middle in the central area; by the short, steep, unarmed, granulate declivity; by the scutellum being longer than wide and by the rather slender, flattened, armed tibiae.

Description.- Body cylindrical, $2.0-4.8 \mathrm{~mm}$. Color of mature specimens black to reddish-brown.

Frons convex, granulate over much of the surface and often densely hairy in the female. Antennal scape but little longer than funicle, widened on distal half; funicle five-segmented, pedicle larger and cupshaped, segments two to five smaller, gradually increasing in size toward the club; elub obliquely truncate with one or two recurved sutures on the pubescent anterior face, basal corneous portion occupying more than half the total length.

Pronotum evenly convex with anterior margin unarmed; dorsal surface usually granulate to finely asperate, more strongly in anterior portion, sometimes punctured in posterior portion. Seutellum longer than wide.

Elytra with striae feebly or not impressed, strial punctures large, usually impressed in regular rows; interspaces slightly wider than striae, smooth; interstrial punctures much smaller and somewhat more abundant than those of the striae, armed with long hair-like setae. Declivity steep, convex or flattened, unarmed; sutrial striae impressed; 
nterspaces foebly granulate.

Middle and hind tiblae rather slender, somewhat flattened distally, muncate at distal end, armed with three to seven teeth (variable within ndividuals).

Vestiture abundant, hair-like.

Iype species.- Bostrichus autographus Ratzeburg, subsequent esignation by Hopkins (1914: 121). 
Key to North American species of Dryocoetes.

1. Pronotum widest at or near the middle, sides rather strongly arcurate (Fig. 3); proepimeron usually with large, shallow punctures; larger species, usually over $3 \mathrm{~mm}$. 2

- Pronotum widest at base or sides parallel, aides weakly arcurat. (Figs. 1 and 2); proeptmeron indiatinctly if at all punetured except in a few affaber; smaller specles, usually under $3 \mathrm{~mm} .4$

2. Female frons with a dense brush of short, yellowish, halr-like setae; declivity of both sexes steop, flattened, with sutural interspece distinetly, sometimes slightly, elevated; disk of pronotum finely densely asperate.

- Female frons with sparsely placed halr-like setae, granulato-punctate with an impunctate smooth median spec; male frons more sparsely olothed with sotae and distinetiy granulate; declivity ovenly convex, not steep, with autural interspace feebly raised; disk of pronotum distinetly punctured with an impunetate or slightly raised median line, asperities anall and low on anterior and lateral portions. autographus (Ratzeburg)

3. Female frons very densely clothed by hair-like setae, concealing the surface of the frons, setae shorter in center, longer and incurved at periphery; pronotum finely asperite over entire surface, 
21

clothed by long, yellow setae; declivity flattened with sutural interspace distinctly raised; from Abies. confusus Swaine

- Female frons less densely halry, not concealing the surface of the frons; disk of pronotum sparsely punctured in median area of posterior half, distinctly asperate on lateral and anterior portions; interspaces of declivity less etrongly impressed than confusus; from Betula and Pyrus. betulae Hopkins

4. Decllvity with the sutural striae deeply impressed, the punctures large, deep; sutural interspace strongly elevated with median row of granules; pronotum about 1.3 times as long as wide, the sides subparallel on posterior two-th1rds; elytral punctures large, close and deep; interspaces narrow on disk, wider on declivity. grantcollis (Leconte)

- Declivity with sutural stria feebly if at all impressed; sutural interspace slightly raised; pronotum less than 1.2 times as long as wide, widest behind middle; elytral punctures smaller, slightly impressed; interspaces as wide or wider than striae on disk and declivity.

5. Female frons closely pubescent, setae long and uneven, those on upper margin longer and incurved; male frons with fewer setae; declivity more strongly flattened, with first and second striae slightly impressed; pronotum less strongly convex; larger, $2.6-3.2 \mathrm{~mm} . ;$ In Pices. affaber (Mannerheim)

- Female frons only slightly more pubescent than male; declivity 
evenly convex; pronotum strongly convex, disk appearing granulate; sma11er, $1.5-2.5 \mathrm{~mm}$.

Sutural striae very slightly impressed, the punctures on declivity reduced in size or Indistinct; frons granulate-punctate with lightly raised, impunctate, longitudinal median line; in Abies Bechelt1 Swaine

Sutural striae distinctly impressed, their punctures not reduced on declivity; median line of fron wider and more distinctly raised; in Picea. cary1 Hopkins 
Dryocoetes autographus (Ratzeburg)

Bostrichus autographus Ratzeburg, 1837, Die Forst-insecten 1: 160. Dryocoetes autographus, Etchhoff, 1864, Berliner Bnt. Zeitschr. 8: 39; Ferrari, 1867, Borkenkäfer, p. 27; Elchhoff, 1879, Roy. sci. soc. Líége, Ken., Série 2,8:284; —, 1881, Die europäischen Borkenkäfer, p. 261; Bedel, 1888, Annales de la Societe Entomologique de France 6: 400; Hamilton, 1890, Int. Americana 6: 44; Hopkins, 1894, Canadian Ent. 26: 279, Smith, 1900, Catalog Ins. New Jersey, p. 363; Barbey, 1901, Les Scolyt1des de 1'Europe central, p. 101; Felt, 1906, New York St. Mus. Mem. B(2): 672; Tred1, 1907, Ent. Blatt. 3: 17; Ni1sima, 1909, Tohoku Imperial Univ., Jour. 3(2): 151; Reitter, 1913, Wlener Ent. Zeltschr. 32: 76; Spessivtseff, 1928, Meddel, fran Statens Skogsforsoksanstalt 24(8): 235; Balachowsky, 1949, Fauna de France 50: 178; Stark, 1952, Fauna U. S. S. R. 31: 336.

Bostrichus septentrionis Mannerheim, 1843, Bull. Naturforsch. Gesellsch. Moscau $16: 126$.

Xyleborus septentrionis, Leconte, 1868, American Ent. Soc., Trans. 2: 161. Dryocoetes septentrionis, Leconte, 1876, American Philos. Soc., Proc. 15:

361; Provancher, 1877, Petite Faune Entomologique du Canada I: 568; Hubbard and Schwarz, 1878, American Philos. Soc, Proc. 17: 643; Eichhoff, 1879, Roy. sci. soc. Liége, Mem., Série 2, 8: 284; 1881, Die europäischen Borkenkäfer, p. 262; Schwarz, 1886, Ent. 


\section{4}

Americana 2: 42; Bedel, 1888, Annales de la Societe Entomologique de France 6: 416; Hamilton, 1889, Amerioan Ent, Soc., Trans. 16: 159; Hopkins, 1893, West VIrginia Agric. Expt. Sta., Bull. 31: 137; Pall and Cockerel1, 1907, American Ent. Soc., Trans. 33; 217; Swaine, 1909, New York St. Mus. Bull. 134. In Report of St. Ent. for 1908, Appendix B, p. 102; Hagedorn, 1910, Coloopterum Catalogus 4: 66; Swaine, 1918, Dom. Canada Dept. Agric. Ent. Branch, Tech. Bull. 14(2): 131; Chamberlin, 1939, The Bark and Timber Beetles of North America, p. 466; ___, 1958, Scolytidae of the Northwest, p. 110.

Bostrichus semicastaneus Mannerheim, 1852, Bull. Soc. Imp. Nat. Moscow 2: 77.

Drrocoetes americanus Hopkins, 1915, U. S. Dept. Agric. Rept. 99, p. 51; Blatchley and Leng, 1916, Rhynchopora of North Eastern America, p. 612, Blackman and Stage, 1918, New York St. College of Foreat., Tech. Pub. 10, p. 59; Swaine, 1918, Dom. Canada Dept. Agric. Ent. Eranch, Tech. Bull. $u_{4}(2): 132 ;$ Blackman, 1919, Phyche $26: 90$; Felt, 1924, Manual Tree Ins., p. 271; Dodge, 1938, Univ. Minnesota Agric. Expt. Sta., Tech. Bull. 132: 55; Chamberlin, 1939, The

Bark and Timber Beetles of North America, p. 466.

Dryocoetes pseudotgugae Swaine, 1915, Canadian Ent. 47: 360; 1918,

Dom. Canada Dept. Agric. Ent. Branch, Tech. Bull. 14(2): 130;

Keen, 1936, U. S. Dept. Agric., Misc. Pub. 273: 125; Chamberin, 1939. The Bark and Timber Beetles of North America, p. 465; 1958, Scolytidie of the Northwest, p. 190.

This species is distinguished from all other North American Dryocoetes by the distinctly punctured pronotal disk, by the convex 
declivity with the sutural interspace only slightly raised, and by the absence of a dense mat of hair on the female frons.

Female.- Length $3.4-5.0 \mathrm{~mm}$. Mature color reddish-brown to black.

Frons broad, strongly convex, flattened just above the epistomal margin; aurface granulate-punctate, clothed with a fow long yellow hairs, with impunctate median smooth space about the size of, or smaller than, antennal club. Antennal club as long as wide, basal corneous portion occupying half the total length. Eyes coarsely granulate and shallowly emarginate.

Pronotum as wide as long, widest at or near middle, sides strongly arcurate and anterior margin broadly rounded; lateral areas and anterior third roughened by small, low confused asperities, disk strongly punctured with median line impunctate or slightly raised. Pubescence consisting of moderately abundant long yellow hair.

Elytra 1.7 times as long as wide; sides parallel, posterior outiirs brozdly rounded; strial punctures large, deep and in regular rows; interstriae usually as wide as striae, punctures as numerous as striae except on declivity, and much smaller, each armed by a moderately long yollow hair-like seta about as long as width of an interspace. Declivity convex, first and third interspaces slightly elevated, second interspace flattened, slightly depressed; interspaces with a median row of small granules armed by moderately long yellow hair.

Male.- Similar to female except frons more sparsely hairy, somewhat broader; declivity more strongly plattened with sutural and third interspaces 1098 elevated; the interstrial granules much reduced or obsolete. Male genitalia as illustrated (Fig. II). 
Type Locality.- Europe, exact locality not know.

Hosts.- P1cea, Tsuga and Pseudotsuga, also recorded from Abies Prazer1, Lirodendron tulipifera and Pinus spp.

Distribution.- Throughout the coniferous forests of Europe and Asia and in North America north of North Carolina and Now Mexico. Specimens examined from: Alaske: Anchorage, Chlchagof Island, Eagle, Juneau, Kasilof, Ketchikan, Matanuska, Ruby, Shagluk, Tolstoi and Yakutat. California: Humbolt Co., Lagunitas, Marian Co. and MeCloud. Colorado: Alma, Craig, Durango and Kenoske Pass. Maine: Beaver Pond, Brunswick, Camp Caribou, Meadows, Crono, Paris and Portland. Massachusettes: Stoneham. Michigan: Grand Island and Marquette. Minnesota: Duluth and Itasca, Montana: MeDonald Lake, New Hampshire: Mt. Washington, Waterville and Webster. New Jersey: Englewood. New Mexico: Capitan. New York: Cicero Swamp, Cranberry Lake, Dundee, Herkimer Co., Ithaca, Mt. Whiteface and Wells. North Carolina: Black Mountain and Pisgah Ridge. Oregon: Astoria, Forest Grove, Santiam and Yarnhill Co. Pennsylvania: North Mountain and Pocono Park. South Dakota: Black Hills and Elnore. Tennessee: Gatlingburg. Utah: Beaver and Uinta National Forest. Vermont: Braintree. Washington: Carson, Easton, Hoquiam, Junetion City, Lake Quiniault, London, Olympic National Forest and Rock Creek. West Virginia: Bayard, Cranesville, Davis, Delslow, Grant Co., Monogalia Co., Morgantom, Randolph and Tucker Co. Wisconsin: Bayfield Co. Alberta: Banff, Calgary, Edmonton, Jasper, Ledue, Lesser Slave Lake, Nordegg and Olds. British Columbia: Avola, "Chilliwack River", Glacier, Inverness, Lorna, Metlakatla, Mission, Pender Harbor, Queen Charlette Islands, Steelhead, Trinity Valley, Vancouver and Wycliffe. Laborador: Goose Bay. Manitoba: "Plquitenay River". 
New Brunswlek: Bathurst, Frederiotion and "Pisiquic Br". Northwest Territorieg: Aklavik and Great Bear Lake. Ontar1o: Frater, Ottarn and Sudbury. Quebee: Aylmer, Duparquet, Isle Perrot, Jollette, "Ialso Dunford", "Lake Opasatika", Lake Tremblante, Montreal, "Nalashquan" and Irinity Bay. Iulon Perritory: Carmacks.

The heretofore European spec1es, antographus, was described by Ratzeburg in 1837. Since that time this apecies has been rocorded from England, Europe and across Asia to Japan. When Hopkins described amerioanus in 1915, he statod that his new species was olosely related and doubtfully distinct from the European autographue. Swaine (1918) also stated that septentrionis was related to autographus. The typo of peeudotsugae has been compsred to a Mannerheim specimen of septentrionis by Wood and found to be ident1eal. After a thorough and frultleas search during this study for characters to distinguish these four speciea, it was concluded that only one variable Holaretio spectes is represented and that the earliest name, autographua, mast be uoed.

Detalis of the geographteal rariation in size found in this spectes is illustrated on page 7.

This species 18 commonly found in the base and roots of dying or injured standing trees, and in felled or windthrown trees. Chamberin (1939) atates that in Douglas fir, the galle ries are short and irregular. The winter hibernation galleries are in the inner bark and are larger than the egg galleries. 


\section{Dryocoetes betulae hopkins}

Jryocoetes eichhoffi Hopkins, 1894 (nec. Ferrarie, 1867), Canadian Ent. 26: 279; —_, 1904, Yearbook of Agric. 1903: 320; Hagedorn, 1910, Coleoptorum Catalogus 4: 67 .

Iryocoetes betulae Hopkins, 1915, U. S. Dept. Agric., Rept. 99: 50; Blatchley and Leng, 1916, Rhynchophora of North Eastern America, p. 611; Swaine, 1918, Dom. Canada Dept. Agric. Ent. Branch, Tech. Bu11. 14(2): 131; Dodge, 1938, Univ. Minnesota Agric. Expt. Sta., Tech. Bull, 132: 55; Blackman, 1922, Mississippi Agric. Expt. Sta., Tech. Bull. 11: 120; Keen, 1938, U. S. Dept. Agric., Misc. Pub. 273: 169; Chamberlin, 1939, The Bark and Timber Beetles of North America, p. 466; Beal and Massey, 1945, Duke Univ. School of Forest., Bull. 10: 159.

Jryocoetes liquidambaris Hopkins, 1915, U. S. Dept. Agric., Rept. 99: 51; Swaine, 1918, Dom. Canada Dept. Agric. Ent. Branch, Tech. Bull. $14(2): 131$.

This species and confusus form a rather sharply defined group sharacterized by the dense brush of hair on the female frons. It may be separated from confusus by the presence of shallow punctures on the disk of the pronotum, by the flatter, and less strongly impressed declivity and by the host.

Female.- Length $2.8-4.5 \mathrm{~mm}$. Mature color reddish-brown. Frons broad, convex; surface granulate, rather densely clothed with 
yellow hairs, (less dense than confusus), not entirely hiding the surface beneath, with a smooth, glabrous, median mooth space, sometimes reaching epistomal margin. Antennal club as long as wide, basal cornoous part occupying half or slightly more of the total length. Eye emarginate and granulate.

Pronotum as long as wide, widest at or about middle, anterior margin broadly rounded, sides strongly areurate; asperate over entire surface except on posterfor portion near median line; punctures shallow, obscure and closely placed in median posterior area.

Elytra 1.7 times as long as wide, sides parallel, brosdly rounded behind; striae punctured in regular rows, slightly or not at all Impressed, the punctures large, impressed; interapses twioe as wide as striae, with numerous, mall punctures esch bearing a moderately long yellow hair. Declivity flat, sutural and third interspace slightly - levated with a median row of small, prominent granules, second Interspace flattened, depressed and granulate, other interspaces granulate toward declivity.

Male.- Similar to female except frons less strongly granulate and pubescence less abundant; declivity steoper, the sutural and third Interspaces more strongly raised, second interspace more strongly depressed, and the granules larger. Male genitalia as illustrated (Fig. 9).

Iype Locality.- Grant County, West Virginia. Hosts.- Betula spectes. Also rocorded from Fagus, Prrus and Hquitamber.

Distribution.- British Columbia to Newfoundland; south in the eastern United States to Mississippi and Florida. 
Specimens were examined from: Mlorida: Mariana. Louisiana:

Tallulah. Maine: Beaver Pond, Camp Caribou, "Camp Kennedy" and Machias. Michigan: Grand Island. Mississipp1: Leland and N1cholson. Montana: Flathead National Porest. New Hampshire: Pranconfa and Waterville. New York: Arton, Cranberry Lake, Elka Park, Maplecrest, Staten Island and Syracuse, North Carolina: Pisgah Ridge. Pennsylvania: Cooksberg and La Porte. Vermont: Hancock. Virginia: Dimal Swamp, Saluda, Vírginia Beach and Wallaceton. West Virginia: Bayard, Davia, Durbin, Grant Co, and Pickins. Wisconsin: Melatine Falls. Alberta: Lesser Slave Lake. Britiah Columbia: Likely, "Rickettg", and Sugar Lake. New Brunswick: Fredericton and Maple Grove. Newfoundland: St. Anthony. Nova Scotia: Stewiacke. Ontario: Algonquin Park, Frater, Kearney and Thor Iake. Quebec: Black River, Knowlton, "Lake Opasatika" and Montreal.

This is the only North American member of the genus that normally attacks broadleaf trees. It generally attacks trees that are injuried or dying and is of no economic importance.

The galleries are irregular with transverse, longitudnal or diagonal branches, according to Beal and Massey, 1945. 
Dryocoetes confusus Swaine

Dryocoetes confusus Swaine, 1912, Canadian Ent. 44: 351; _, 1918,

Dom. Canada Dept. Agric. Ent. Branch, Tech. Bull. $\mathbb{1}_{4}(2), 131$;

Mather8, 1931, Jour. Econ, Ent. 24: 775; _-, 1931, Canadian

Ent. 63: 247; Keen, 1938, U. S. Dept. Agric., Misc. Pub. 273: 163,

165; Chamberlin, 1939, The Bark and Timber Beetles of North

America, p. 467; __, 1958, Scolytidae of the Northwest, p. 188.

Dryocoetes abletis Hopkins, 1915, U. S. Dept. Agric. Rept. 99: 52;

Swaine, 1918, Dom. Canada Dept. Agric. Ent. Branch, Tech. Bull.

$14(2): 131$.

This species is closely related to betulae, but may be separated by the absence of punctures on the pronotal disk, by the very dense mat of hajr on the female frons, by the more strongly impressed elytral declivity and by the host.

Female. - Length $3.4-4.3 \mathrm{~mm}$. Color of mature specimens reddishbrown to black.

Frons flat; surface granulate, with a shallowly impressed postopistomal impression, clothed on a circular area by a very dense brush of reddish-brown to yellow hair-like setae, longer at margin; opistomal margin fringed by closely placed yellow hair. Antennal club wider than long, basal corneous part occupying little more than half the total length. Syes coarsely granulate, shallowly emarginate.

Pronotum 1.1 times wider than long, widest at or near middle; 
anterior margin broadly rounded, sides strongly angulate; anterior and lateral portions finely asperate, asperities low, confused, the disk granulate-asperate, clothed by erect reddish hair.

Elytra 1.6 times longer than wide, sides parallel, broadly rounded posteriorly; strial punctures smaller than in other species, weakly impressed in regular rows, sutural strice more impressed; interspaces at least twice as wide as striae, the punctures much smaller and more numerous, each armed by an erect yellowish hair. Declivity convex; strial punctures smaller, obsolete in some specimens; sutural interspace raised and granulate-setose, granules prominent, uniseriate; second interspace impressed, less granulate-setose; third interapace ralsed. Male.- Similar to female except frons only sparsely clothed by yellowish hair, surface granulate-punctate, with an impunctate, smooth, median space and a transverse impression just above epistomal margin; elytral declivity with the sutural interspace more strongly elevated and second one more strongly impressed, granules larger. Male genitalla as illustrated (Fig. 10).

Type Locality.- Colorado, exact locality not known. Hosts.- Abies lastocarpa, less comonly from other species of Abies and Picea engelmanni.

Distribution.- Throughout the range of its host in western North America from British Columbia to New Mexico.

Specimens examined from: Arizona: San Franscisco Mountains. Colorado: Jackson Co., Newcastle, Rabbit Ears Pass and White River National Forest. Idaho: Lakeview and Coeur d'Alene. Montana: Bighorn Co. and Glacier National Park. New Mexico: Coyote. Oregon: Bourne and Sumpter. Utah: Cedar Break National Monument, La Sal Mountains, Mant1 
lational Forest, Wasatch National Forest and Wolf Creek Pass (Duchesne Co.h yroming: Yellowstone National Park and Wapiti. Alberta: Jasper and esser Slave Lake. Britigh Columbia: Allen Lake, China Valley Ranger itation, Copper Basin, Fishtrap, Green Mountains, Hedley, Hope Surmit, inverness, Lorna, Merritt, Niconen Ridge, Stanley, Terrace and Williams ake.

This species attacks Abies lasiocarpa and less commonly other trees $n$ the genus Abieg. It is the most aggressive North American member of he genus and has been known to attack green trees. According to Swaine 1918), it attacks and kills healthy balsam in eastern Brit1sh Columbia nd northem Alberta. It has also been observed to k1ll overmature Ipine fir in Utah.

The gallery consists of a small, circular nuptial chamber entirely n the phloem, with several radiating egg galleries which may score the iapwood (Keen, 1938). 


\section{Dryocoetes granicollis (Leconte)}

Xyleborus granicollis Leconte, 1868, American Ent. Soc., Trans. 2: 162. Dryocoetes granicollis Leconte, 1876, American Philos. Soc., Froc. 15: 861; Hubbard and Schwarz, 1878, American Philos. Soc., Proc. 17: 643: Smith, 1900, Cat. Ins. New York, p. 363; Swaine, 1909, New York St. Mus. Bull. 134, In Rept. of St. Ent. for 1908, Appendix B, p. 103; Blatchley and Leng, 1916, Rhynchophora of North Eastern America, p. 611; Swaine, 1918, Dom. Canada Agrio, Ent. Branch, Tech. Bull. $\mathbb{1}_{4}(2): 130$; Chamberlin, 1939, The Bark and Timber Beetles of North Amertca, p. 465.

This species is not closely allied to any other species in the North American fauna. Its closest known relative evidently is the European villosus.

It may be distinguished from other North American representatives of the genus by the strongly punctured elytra, by the strongly elevated sutural interspace on the declivity, by the strongly impressed first striae and by the elongate pronotum with its parallel sides.

Female.- Length $2.3-3.0 \mathrm{~mm}$. Mature color reddish-brown.

Frons flattened or slightly concave with indistinctly raised longitudinal median line just above epistomal margin, occassionally absent; smooth and minutely granulate, punctured near vertex; lateral areas of epistomal margin slightly raised and granulate. Pubescense consisting of sparsely placed hairs. Eye moderately granulate and 
ilightly omarginate. Antennal elub as long as wide, basal corneous part scupying about half the total length.

Pronotum 1.3 times longer than wide, sides subparallel on posterior iwo-thirds, anterior margin broadly rounded; basal angles strongly urcurate; anterior and lateral portions finely asperate-granulate, Indistinctly subgranulate and punctured on disk; clothed by abundant, noderately long yellow hair.

Elytra 1.32 times as long as wide; sides parallel; striae strongly junctured in regular rows, sutural atriae impressed, punctures large and leep; Interspaces narrower than strlae; the punctures much smaller, each 3rmed by a moderately long, yellow hair. Declivity convex; sutural striae deeply impressed, the punctures large, coarse and close; sutural Interspace very strongly elevated and distinctly granulate; other leclivital interspaces elevated and granulate.

Male.- Similar to female except frons less densely hairy and leclivity steeper with sutural striae more impressed. Male gentalia as LIustrated (Fig. 7.).

Type Locality.- Sullivan County, Pennsylvania. Hosts.- Plcea species. There are also records from Juglanda, jestanea and Abies, but these probably are accidental hosts, misidentifications or errors in labelling of the host.

Distribution.- An uncommon species in northeastern North America, from Quebec to North Carolina.

Specimens examined from: District of Columbla. Kansas: Douglas Co. Kentucky: Noble. Maine: "Agriculture Experiment Station". New Jersey: Orange Mountains. North Carolina: Tryon. Ohio: Marion Co. Pennsylvania: Arendtsville, Pen Kar and Swarthmore. West Virginia: 
Randolph Co. New Brunswick: "Pisiquil Br.". Quebec: Chelsea and Gespe.

This spectes is one of the rarest species in this genus in

North America. Nothing of the biology is known. 


\section{Dryocoetes affaber (Mannerheim)}

trichus affaber Mannerheim, 1852, Bull. Soc. Imp. Nat. Moscow 2: 77. eborus affaber, Leconte, 1868, American Ent. Soc., Trans. 2: 162. ocoetes affaber, Leconte, 1876, American Philos. Soc., Proc. 15: 361;

Elchhoff, 1879, Roy. sel. soc. Liége, Mem., Série 2, 8: 286;

Schwarz, 1888, Ent. Soc. Washington, Proc. 1t 80; Hopkins, 1893, West Virginia Agric. Expt. Sta., Bull. 32: 212; Schwarz, 1895, Ent. Soc. Washington, Proc. 3: 143; Felt, 1906, New York St. Mus. Mem. 8(2): 752; Swaine, 1909, Now York St. Mus. Bull. 134, In Rept. of St. Ent. for 1908, Appendix B, p. 101; Hagedorn, 1910, Coleopterorum Catalogus, p. 65; Blatchley and Leng, 1916, Rhynchopors of North Eastern America, p. 613; Swaine, 1918, Dom. Canada Dept. Agric. Ent. Branch, Tech. Bull. 14(2): 132; Keen, 1936, U. S. Dept. Agric., Misc. Pub. 273: 165; Dodge, 1938, Univ. Minnesota Agric. Bxpt. Sta., Tech. Bull. 132: 55; Chamberlin, 1939, The Bark and Timber Beetles of North America, p. 467; 1958,

The Scolytidae of the Northwest, p. 189. ocoetes pubescens Swaine, 1912, Canadian Ent. 44: 350; 1912

Dom, Canada Dept. Agric. Hint. Branch, Tech. Bull, 14(2): 132;

Chamberlin, 1939, The Bark and Timber Beetles of North America, p. 468 . ocoetes piceae Hopkins, 1915, U. \$. Dept. Agric. Rept. 99: 51; Blatchley and Leng, 1916, Rhynchopora of North Eastern America, p. 
613; Swaine, 1918, Dom. Canada Dept. Agric. Ent. Branch, Tech. Bul1. 14(2): 30; Dodge, 1938, Univ. Minnesota Agric. Expt. Sta., Tech. Bull. 132: 55; Chamberlin, 1939, The Bark and Timber Beetles of North America, p. 468; Beal and Massey, 1945, Duke Univ. School of Forest., Bull. 10: 160.

This specieg does not appear to be related to any North American ipecies. It may asily be recognized by the pronotum being widest behind ihe middle, by the flattened, steep, slightly impressed declivity, by the ubescent female frons and by its size.

It is apparently the most common Dryocoetes in North America. Female.- Length $2.5-3.3 \mathrm{~mm}$. Mature color dark reddish-brown to .Imost black.

Frons flattened; surface granulat-punctate, clothed by moderately lense long hair, not hiding the surface beneath, hairs longer and ncurved above; epistomal margin fringed with closely placed yellow hatr. intennal club as long as wide, basal cornenus part occupying half the sotal length.

Pronotum 1.1 times as long as wide, widest well behind middle; Interior margin narrowly rounded; sides strongly arcurate; asperate over the lateral areas and anterior half, moderately granulate on disk behind. 'ubescence composed of abundant long yellow hair, shorter on disk.

Elytra 1.5 times as long as wide, sides parallel, broadly rounded sehind; strial punctures large, smaller toward declivity, impressed in -egular rows; interatriae smooth, occasionally roughened, at least twlce 1s wide as striae; the punctures 1rregular and much smaller than those of 3triae, somewhat 1088 numerous, each puncture armed by a long yellow hair; sutural interspace elevated slightly on posterior half of disk. Declivity 
" flat, sutural interspace and third interspace slightly elevated with a median row of prominent granules. Second interspace flattened, impressed, with a median row of prominent granules, less numerous than the strial punctures; other interspaces uniseriately granulate-setose.

Male.- Similar to female except frons with hair less abundent; declivity wth first and third interspaces more strongly elevated and with their granules smaller. Male genitalla as 1llustrated (Fig. 8). Type Locality.- Alaska, the exact location not given. Hosts.- Plcee species; also recorded from Abies, Larlx and Pinus. Distribution.- The spruce forests of North America from Canada and Alaska south to North Carolina and New Mexico.

$$
\text { Specimens examined from: Alaska: Ardreafsky, Eagle, Fairbanks, }
$$
Fort Yukon, Homer, Juneau, Kenai, Matanuska, McGrath, Naknek Lake, Patterson Bay, Rampert House, Tolstoi and Yalutat. Colorado: Craig, Grand Lake, Gunnison National Forest, Jackson Co., Longmont, Newcastle and Snowmass, Idaho: Coeur d'Alene, Collins, Kaniksu National Forest and Lakeview. Maine: Allagash, Beaver Pond, Camp Caribou, Cupsuptic and Lake Moxie. Michigan: Grand Island and Marquette. Montana: Bozeman, Columbia Falls, Glacier National Park, Lake McDonald and Lincoln Co. New Hampshire: Coos Co., DLxville, Waterville and Wonalancet, New Mexdco: Sacremento Mountains. New York: Cranberry Lake and Syracuse. North Carolina: "Pink Beds", P1sgah Ridge and S1lver Mountains. Oregon: Ahlers, Cable Cove, Push, Saint Helens and Seaside. Pennsylvania: North Mountain. South Dakota! Black Hills and Elmore, Utah: Beaver, La Sal Mountains, Logan Canyon, Mammoth Mountain and Wolf Creek Pass (Duchesne Co.). Washington: Hoquiam and Lake Quiniault. West Virginia: Burbin, Craneaville, Davis, Grant Co., Pocahontas Co., Randolph Co., and Shavers 
Fork Mountain. Wisconsin: Point Edwards. Wyoming: Encampment. Alberta: Banff, Edmonton, Jasper National Park, Lesser Slave Lake and 01ds. British Columbia: Barkerville, Cherry Creek Valley, Fernie, Glenora, Hedley, Hope Mountains, Inverness, Lorna, Lumby, Merritt, Princeton, Spa Lake, Stanley, Swift River and Vancouver. Laborador: Matamek RIver. Manitoba: Winnipeg. New Brunswick: Bathurst, Maple Grove, "Plsiquit Br.", Plaster Rock and Tobique River. Northwest Texritorles: Aklavak, Great Bear Lake and Mackenzie River. Ontario: Algonquin Park, Chalk River, James Bay, Nipigon and Prince Edward Co. Quebec: Aylmer, Caspe, "Lake Dunford", "Lake Opasatika", Laniel, Montrea1, Rupert House and Saint Anne's. Yukon Territory: Carmacks, Dry Creek and Whitehorse.

Hopkins (1915a) described piceae on its smaller size and eastern distribution and Swaine (1912) described pubescens on its apparently larger declivital punctures. From the discussion of characters presented previously it is seen that these characters are merely variations within the population. Therefore, in the absence of consistant morphological differences, only one species is represented.

Keen (1938) states that this specles attacks the top of felled and dying spruce in the western United States. It has been observed attacking both the upper and lower bole and stumps of standing and felled spruce in Utah, Colorado, eastern Canada and Alaska.

The adults construct a central nuptiel chamber from which the egg galleries, usually three in number, radiate (Chamberlin, 1958). 


\section{Dryocoetes sechelti Swaine}

ocoetes sechelti Swaine, 1915, Canadian Ent. 47:359; 1918 ,

Dom. Canada Dept. Agric. Ent. Branch, Tech. Bull. 14(2), 130;

Chamberlin, 1939, The Bark and Timber Beetles of North America, p. 465; 1958, The Scolytidae of the Northwest, p. 191.

This species is one of the smallest species in the genus. It is Led to, but may be separated from caryi by the smaller declivital letures on the sutural striae, by the obsclete median line of the frons 1 by the host. It may be distinguished from other nembers of the genus its small size, by the more strongly precipitous anterior portion of pronotum and by the steep, plat declivity.

Fema 1e.- Length $2.0-2.5 \mathrm{~mm}$. Mature color reddish-brown, lege

l antenne sometimes lighter.

Frons convex above; surface densely granulate-punctate, clothed by lerately long yellow hair, with slight transverse impression above stomal margin, also with longitudinal, scarcely raised, impunctate lian Ine from epistomal margin to vertex; epistomal margin with .nge of closely placed, long yellow hair in median area. Antennal club long as wide, corneous basal part occupying very slightly less than f the total length. Eye granulate; shallowly emarginate.

Pronotum widest behind middle; sides slightly rounded, basal jles strongly arcurate, anterior margin moderately rounded; granulate ir disk, asperate on anterior and lateral areas, asperities low 
confused and closely placed. Pubescence consisting of moderately long yellow hair on sides, shorter on disk,

Elytra 1.4 times as long as wide; sides perallel; strial punctures large, impressed, in regular rows, each puncture usually with a very short hair, sutural striae slightly impressed, others slightly or not at all Impressed; interstriae smooth, at least twice as wide as striae, interstrial punctures much smaller and more numerous, armed by yellow hair shorter than width of an interspace. Declivity convex above, somewhat flattened below with sutural interspace slightly raised; strial punctures reduced usually becoming obsolete toward apex; Interspaces with median row of very small granules each bearing a short yellow hair. Male.- Similar to female except frons less densely hairy and declivital granules smaller or obsolete. Male genitalla as illustrated (Fig. 6).

Type Locality.- Sechelt, British Columbia. Host.- Abies lasiocarpa. Distribution.- Uncomon in western coniferous forests from British Columbia to Colorado.

Specimens examined from: Colorado: Newcastle and Uncompangre National Forest. Montana: Glacier National Park. Oregon: Suttle Lake. Utah: La Sal Mountzins and Logan Canyon. Britioh Columbia: Lorna, Sechelt and Stanley.

This spectes breeds in the lower portion of the bole in small supressed trees less than eight inches in diameter (Wood, personal communication). 


\section{Dryocoetes cary1 Hopkins}

Dryocoetes caryi Hopkins, 1915, U. S. Dept. Agric., Rept, 99: 50;

Chamberlin, 1939, The Bark and Timber Beetles of North America, p. 468.

This species is very closely related to sechelti Swaine, but differs in the more prominent, impunctate, longitudinal median line of the frons, and by the large, impressed punctures of the sutural striae which are not reduced on the declivity.

Femsle.- Length $2.1-2.7 \mathrm{~mm}$. Mature color reddish-brown. Frons convex above, flattened below; surface moderately granulatepunctate, with a prominent, impunctate median line, narrower toward epistomal margin; epistomal margin slightly sinuste, lateral margins not raised. Fubescence short, moderately abundant. Antennal scape about 1.5 times longer than the funicle, widened at the distal end; club round, as long as wide, basal corneous portion occupying half the total length. Pronotum 1.07 times longer than wide, widest behind middle; oldes and anterior margin moderately narrowly rounded, basal angles more broadly rounded; strongly convex in profile, anterior portion steeper and asperite, sumbit behind middle, uniformly granulate in posterior and Lateral portions.

Elytra 1.4 times longer than wide, sides parallel, apex subtruncate wth angles broadly rounded; sutural striae slightly impressed, others not impressed, the punctures moderately large and Impressed; interspaces 
smooth, about one and one-half times wider than striae, punctures minute and more numerous than those of strise. Declivity somewhat flattened; sutural striae slightly impressed with punctures not reduced, second, third and fourth striae with punctures often much reduced to obsolete; interspaces with $\operatorname{sma} 11$, acute granules.

Male.- Simlar to female except pubescence of frons shorter and less abundant; declivital granules somewhat larger. Male genitalia as 11.lustrated (Fig. 5).

Type Locality.- Camp Caribou, Maine.

Hosts.- Picea engelmanni, P. rubra and $P_{1}$ glauca.

Distribution.- The northern confferous forests of North America from British Columbia to Maine, south to North Carolina and Wyoming. Specimens examined from: Maine: Camp Caribou. North Carolina: Cherokee, Wyoming: Laramie. Alberta: Crowsnest. British Columbia: Lorna. Quebec: Chelsea and Qaspe. This species evidently is quite rare; only a very few collections having been made aince the type was collected. It breeds in the bole of sma11, weakened, shaded-out, supressed spruce. In Quebec it was taken in association with Xylechinus americanus Blackman (Wood, personal communteation). 
LITERATURE CITED

Balechowsky, A. 1949. Fauna de France 50, Coleoptera: Scolytides. 320 p., $300 \mathrm{figs}$. P. Lechevalier, Paris.

Beal, J.A. and C. L. Massey. 1945. Bark beetles and ambrosia beetles (Coleoptera: Scolytidae): With special reference to species occurring in North Carolina. Duke Univ. School of Forest., Bull. 10. $178 \mathrm{p}, 28 \mathrm{pls}$.

Browne, F. G. 1959. Notes on two Malayan Scolytid bark-beetles. Malayen Forester 22(4): $292-300$.

Chamberlin, W. J. 1939. The bark and timber beetles of North America north of Mexico. vi- 513 p., 321 fig., 5 plo, Oregon State College Cooperative Association, Corvallis.

Eichhoff, W. 1864. Üeber die Mundthelle u, die Fühlerbildung der europäischen Xylophagi sans. striet. Berliner. Ent. Zeitschr. $8: 17-46$.

- 1879. Rat1o, descriptio, mendatio, eorum tomicinorum. iv - 531 p., 5 pls. F. Hayez, Bruxellis.

- 1881. Die europäjschen Borkenkäfer. vi - 315 p., 109 figs. J. Springer, Berlin.

Hopkins, A. D. 1914. List of generic names and their type-species in the Coleopterous superfamily Scolytoidea. U. S. Nat. Mus., Proc. $48: 115-136$

- 1915a. Classiflcation of the Cryphalinae, with descriptions of new genera and species, U. S. Dept. Agric., Office of the Sec., 45 
Report 99: $1-75$.

- 1915b. Preliminary classification of the superfamily Scolytoldea. U. S. Dept. Agrie., Tech. Ser., No. 17, pt. 2, p. 165 - 232.

Keen, F. P. 1938. Insect enemies of western forests. U. S. Dept. Agric., Misc. Pub. 273. 210 p., 111us,

Leconte, J. R. and George H. Horn. 1876. The Rhynchopora of America, north of Mexico. Amer. Philos, Soc., Proc. 15(96): xvi - 455.

Mannerheim, C. G. 1843. Beitrag zur Kaefer-fauna der Aleutischen Inseln, der Insel Sitkha und Neu-Californiens, Naturf. Gesel. Moscau, Bul1. 16, 142p.

- 1852. Zweiter Nachtrag zur Kaefer-fauna der Nord-Amerikanischen Laender des Russischen Reiches. Bull. Soc. Imp. Nat. Moscau 2, $105 \mathrm{p}$.

Mathers, W. G. 1931. The biology of Canadian bark-beetles. The seasonal history of Dryocoetes confusus Sw. Canadian Ent. 63: $247-248$.

Swaine, J. M. 1912. New species of the family Ipldae (Coleoptera). Canadian Ent. 44: $349-353$.

- 1915. Descriptions of new species of Ipidae (Coleoptera). Canadian Ent. 47: $355-369$. - 1918. Canadian bark beetles. Part 2. Dom. Canada Dept. Agric. Ent. Braneh Bull. 14, 143 p. 
IEGEND

Fig. 1. Dorsal aspect of pronotum of Dryocoetes granicoli1s. Fig. 2. Dorsal aspect of pronotum of Dryocoetes sffaber. Fig. 3. Dorsal aspect of pronotum of Dryocoetes autographus. Fig. 4. Antenna of Dryocoetes affaber. posterior aspect. Fig. 5. Male genitalia of Dryocoetes caryi. lateral sspect. Fig. 6. Male genitalia of Iryocoetes sechelti, lateral aspect. Fig. 7. Male genitalia of Dryocoetes granicollis, lateral aspect. Fig. 8. Male genitalis of Dryocoetes affaber, lateral aspect. Fig. 9. Malo genitalia of Dryocoetes betulae, latoral aspect. Fig. 10. Male genitalia of Dryocoetes confusus, lateral aspect. Fig. 11. Male genitalia of Eryocoetes autographus. Lateral aspect. 


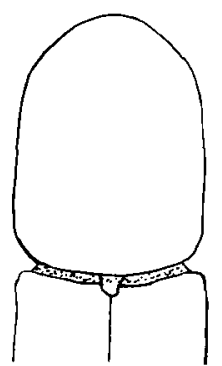

I. GRANICOLLIS
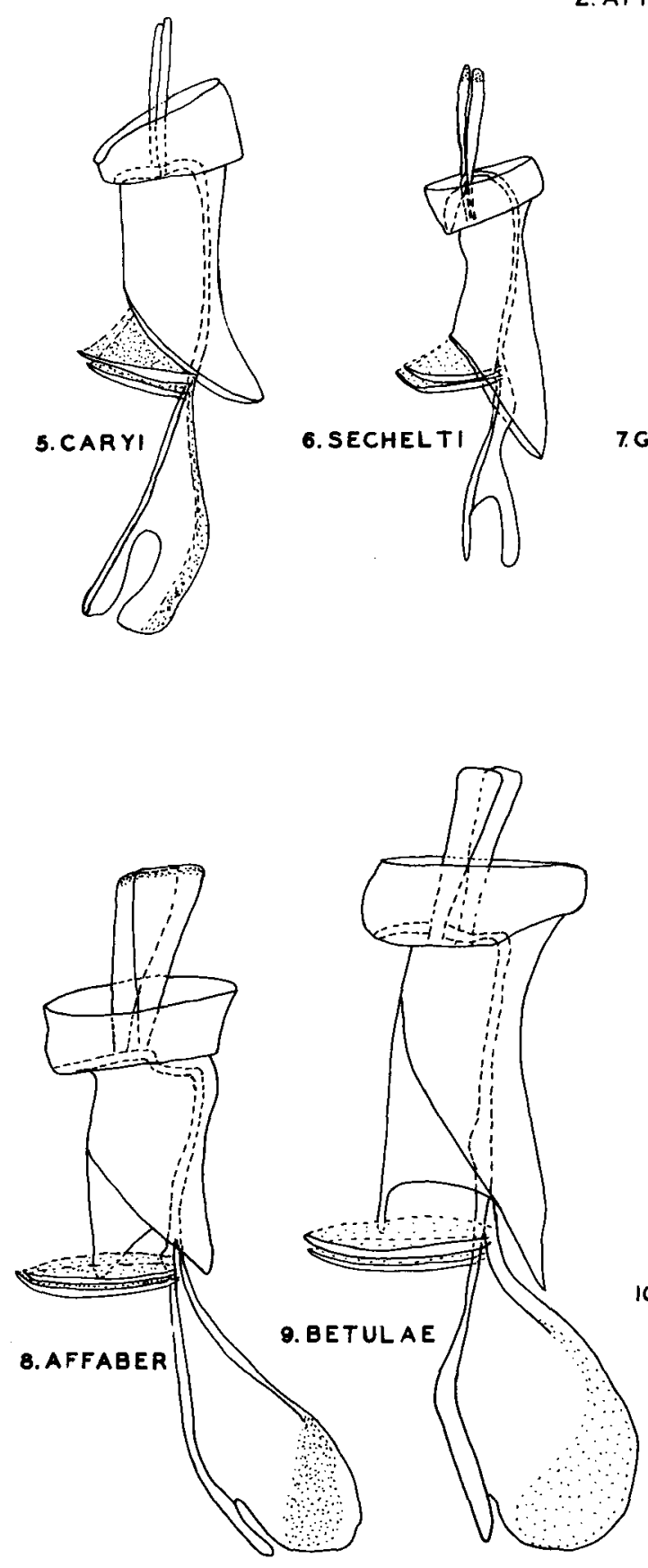

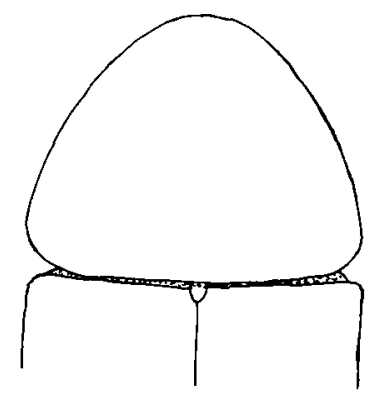

2. AFFABER
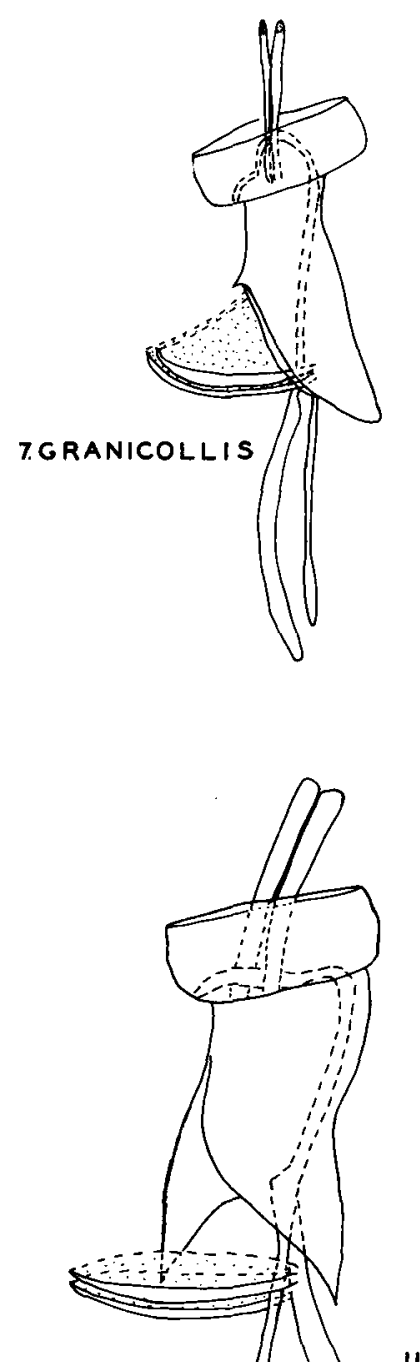

10. CONFUSUS
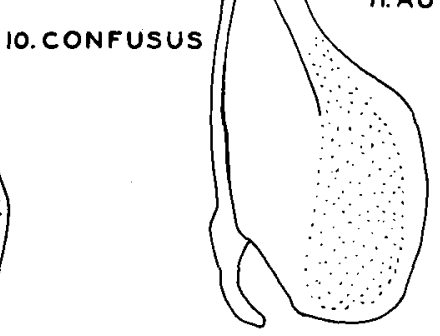

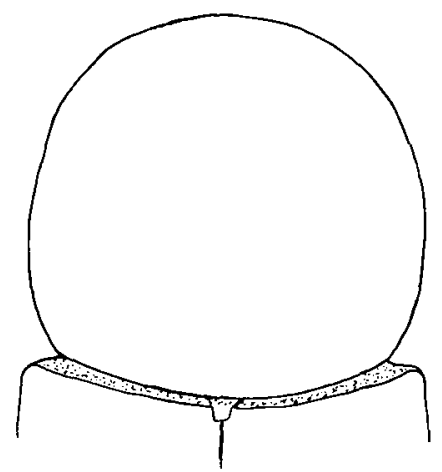

3. AUTOGRAPHUS
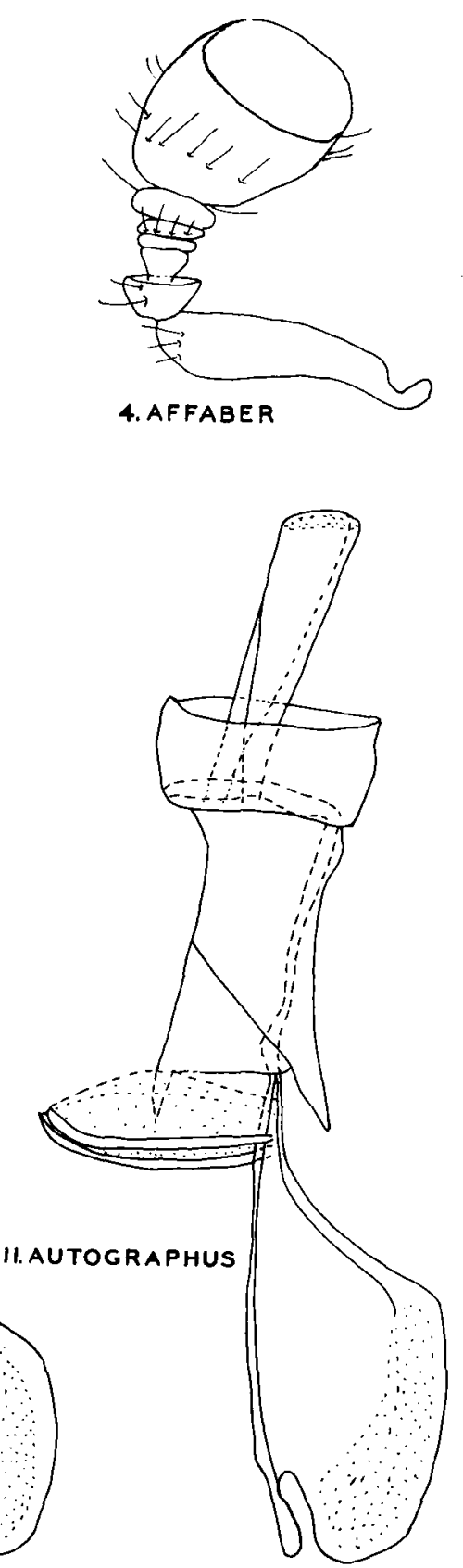
BARK BEETLES OF THE GENUS DRYOCOETES

(COLEOPTERA: SCOLYTIDAE) IN NORTH AMIBRICA

AN ABSTRACT

SUBMITTED TO

THE DEPARTMENT OF ZOOLOGY AND ENTOMOLOGY

BRIGHAM YOUNG UNIVERSITY

IN PARTIAL FULFILLMENT OF THE REQUIREMENTS FOR

THE DEGREE OF

MASTER OF SCIENCE

\author{
BY \\ DONALD EDWARD BRIGHT, JR. \\ JUNE, 1961
}


This abstract by Donald Edward Bright, Jr. 18 accepted in its present form by the Department of Zoology and Entomology of Brigham Young University as satisfying the abatract requirement for the degree of Master of Science.

June, 1961 


\section{ABSTRACT}

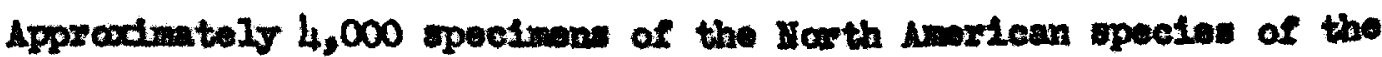
I beotle genus Dxyooostes was comined during this taxonomic atudy. molote doccoriptions and a by wore prepared for the seven Yorth arlona epecter. Dietributionel data, biologionl notes and a bltography for asch apectes are preaented. The nowphologleal chareoters

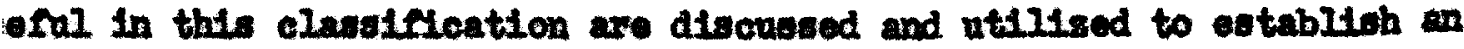
perent phylogeny.

The important external characterw need in this clevalfiention include - chope and sculpture of the pronotrum, the pubesonnce of the formile ons, the degree of Inpression of the sutwral atriae on the doclivity d the ahape of the declivity. The mot signigicant charactere wore and in the thape of the ondopballic portion of the nale gonitelin Ioh are 111uatrated.

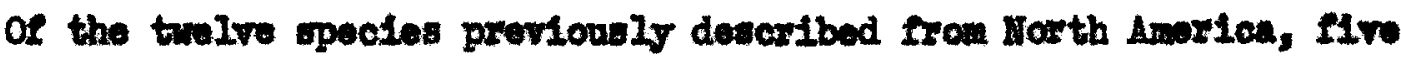

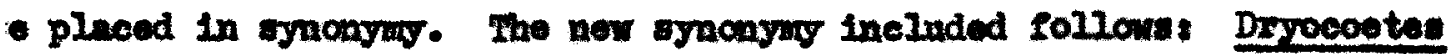

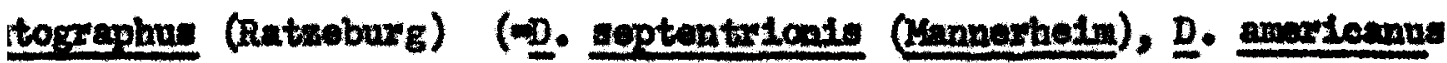

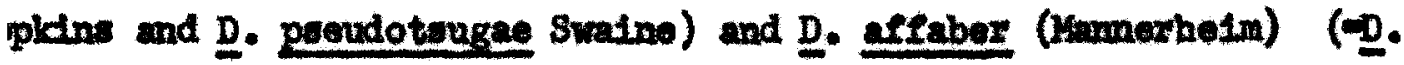
cone Hopldin: and D. pubesoens Swatne).

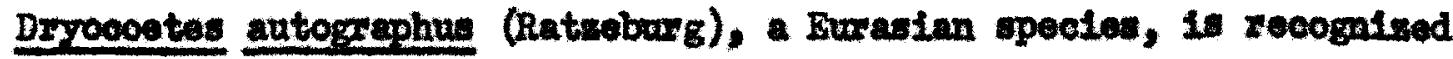
F the firat tim in North Ameriean fama. Signifleant cxtenalons of - distributions of secheltt Sraine and exyl Hopleing are included. 